\title{
PENERAPAN MODEL PEMBELAJARAN PROYEK (PROJECT BASED LEARNING) BERBANTUAN CLAY UNTUK MENINGKATKAN HASIL BELAJAR BIOLOGI SISWA KELAS XI MIPA 5 SMA NEGERI 1 SEMARAPURA SEMESTER GANJIL TAHUN PELAJARAN 2015/2016
}

\author{
Ni Luh Ratna Tirtawati \\ SMA Negeri 1 Semarapura \\ email: niluhratnatirtawati@yahoo.co.id
}

\begin{abstract}
ABSTRAK
Penelitian ini bertujuan untuk meningkatkan hasil belajar biologi pada siswa kelas XI MIPA 5 SMA Negeri 1 Semarapura semester ganjil tahun pelajaran 2015/2016 dengan menerapkan PjBL berbantuan clay. Subjek penelitian ini berjumlah 38 orang, Objek penelitian berupa hasil belajar biologi. Penelitian ini dilaksanakan dalam dua siklus, dan masing-masing siklus terdiri dari empat tahapan, yaitu 1) perencanaan, 2) pelaksanaan tindakan, 3) observasi dan evaluasi tindakan, dan 4) refleksi. Siklus I dilaksanakan materi pokok sel, sedangkan siklus II diterapkan pada materi pokok sistem rangka. Untuk siklus I dan siklus II dirancang masing-masing 4 Jam pelajaran (2 kali tatap muka). Untuk hasil belajar biologi juga mengalami peningkatan dari siklus I ke siklus II, dari rata-rata 70,53 menjadi 85,26 dengan persentase tuntasan 55,26\% menjadi 94,74\%. Kesimpulan dari penelitian ini bahwa PjBL dapat meningkatkan hasil belajar biologi pada siswa kelas XI IPA 5 SMA Negeri 1 Semarapura semester genap tahun pelajaran 2015/2016.
\end{abstract}

Kata kunci: Model Pembelajaran Proyek, Hasil Belajar, Clay.

\begin{abstract}
This research aims to know Project Based Learning to increase biology learning outcome to the students of XI MIPA 5 of SMA Negeri 1 Semarapura in the even semester in the school year 2015/2016. The research subject are 38 students, research objects include biology lesson learning outcome. The research is carried out into two cycles consists of four (4) stages, those area: 1) Planning, 2) action realization, 3) Observation and evaluation, and 4) reflection. Cycle one (I) is carried out the main respiration system, while cycle two (II) is given the main reproduction system, for cycle one and two are planned (six) hours lesson (three times face to face teaching and learning process). The result of biology learning is also increases from cycle one to cycle two with the average 70.53 becomes 85.26 with the total percentage 55,26 \% becomes 94,74\% the result of biology lesson is also increasing from cycle one to cycle two. So the conclusion of this research is that PjBL can increase of biology to the students of XI IPA 5 SMA Negeri 1 Semarapura.
\end{abstract}

Key words: Project Based Learning, Learning Outcome, Clay. 


\section{PENDAHULUAN}

Pendidikan mempunyai tugas menyiapkan sumber daya manusia untuk pembangunan. Di era pembangunan selalu diupayakan seirama dengan tuntutan jaman. Implikasi dari segenap perubahan yang terjadi mempengaruhi aspek pendidikan di Indonesia. Bangsa Indonesia dituntut untuk merancang sistem pendidikan yang lebih kreatif, dinamis dan responsif terhadap perubahan serta kecenderungan-kecenderungan yang sedang berlangsung.

Kegiatan utama dalam proses pendidikan di sekolah adalah proses belajar mengajar. Proses belajar mengajar pada dasarnya merupakan proses interaksi antara dua unsur, yaitu siswa yang sedang belajar dan guru yang mengajar, dan berlangsung dalam suatu ikatan untuk mencapai tujuan pembelajaran yang telah ditetapkan. Proses belajar mengajar diartikan sebagai suatu interaksi antara siswa dan guru dalam rangka mencapai tujuan (Solihah, 2013). Proses pembelajaran di dalam kelas tidak hanya untuk menyampaikan informasi yang belum diketahui dari siswanya. Sehingga arah transfer ilmu pengetahuan dalam proses pembelajaran tidak hanya dari guru kepada siswa, tetapi bisa juga dari siswa kepada guru. Oleh karena itu sikap untuk terbuka terhadap ilmu pengetahuan harus dimiliki oleh guru dan siswa.

$$
\text { Menteri pendidikan dan }
$$

kebudayaan Anies Baswedan mengatakan berdasarkan kajian Organisation for Economic Cooperation and Devel Opmeni (OECD) bahwa kemampuan matematika dan membaca anak Indonesia sangat rendah (Bali Post, 2015). Berdasarkan observasi hasil belajar biologi yang peneliti lakukan pada kelas X MIPA 5 semester genap tahun pelajaran 2014/2015 berdasarkan rata-rata nilai ulangan umum, ternyata baru mencapaian 69,92 dengan ketuntasan belajar secara klasikal 44,74 \%, Nilai rata-rata ini masih jauh dari KKM mata pelajaran biologi di sekolah ini yaitu 75. Berdasarkan hasil diskusi peneliti dengan guru yang mengajar di kelas $\mathrm{X}$ MIPA 5, ditemukan bahwa beberapa hal yang menyebabkan tidak maksimalnya hasil belajar siswa pada mata pelajaran Biologi antara lain: 1) Siswa kurang mampu merekuntruksi pengetahuan yang sudah mereka miliki dikaitkan dengan pengetahuan baru yang didapat, 2) Siswa belum mampu menyelesaikan permasalahan yang berkaitan langsung dengan kehidupan nyata sehari-hari. Walaupun sudah berbagai model pembelajaran yang di terapkan oleh guru tapi sampai saat ini belum menunjukkan hasil yang maksimal, mungkin hal ini terjadi karena tidak semua pengetahuan dapat diterima dengan mudah oleh siswa. Pengetahuan hafalan dapat ditransfer langsung. Namun pengetahuan fisik dan logika tidak dapat ditranfer secara utuh dari pikiran guru ke pikiran siswa tetapi harus dibangun sendiri oleh siswa sebagai usaha keras siswa untuk mengorganisasi pengalamannya dengan skema atau struktur mental yang telah ada.

Biologi adalah ilmu yang berhubungan dengan kehidupan yang diperoleh dan dikembangkan berdasarkan pengamatan dan eksperimen/percobaaan (induktif) dan teori (deduktif), sedangkan proses pembelajarannya dilaksanakan secara inkuiri ilmiah (scientific inquiry) untuk menumbuhkan kemampuan berpikir, bekerja dan bersikap ilmiah serta mengkomunikasikannya sebagai 
aspek penting kecakapan hidup, atau dengan kata lain bahwa pembelajaran biologi dikurikulum 2013 lebih menekankan pada pemberian pengalaman belajar secara langsung melalui penggunaan dan pengembangan keterampilan proses dan sikap ilmiah (Kemendikbud, 2014)

Untuk memperbaiki dan meningkatkan mutu proses dan hasil pembelajaran maka dilakukan proses penyelarasan dan menyerasian proses pembelajaran dengan pandanganpandangan dan temuan-temuan baru di berbagai bidang falsafah dan metodologi pembelajaran yang senantiasa dimutakhirkan, diperbaharui, dan dikembangkan oleh berbagai kalangan khususnya kalangan pendidikan-pengajaran-pembelajaran.

Salah satu model pembelajaran yang didapat dari proses pemutahiran, pembaharuan dan pengembangan oleh para ahli adalah model pembelajaran Proyek (Project Based Learning) yang biasa disingkat dengan $\mathrm{PjBL}$, dimana model pembelajaran ini direkomendasikan untuk digunakan sebagai salah satu model pembelajaran dalam kurikulum 2013. Keunggulan model pembelajaran proyek yaitu Peserta didik melakukan eksplorasi, penilaian, interpretasi, sintesis, dan informasi untuk menghasilkan berbagai bentuk hasil belajar, dan model pembelajaran proyek menggunakan masalah sebagai langkah awal dalam mengumpulkan dan mengintegrasikan pengetahuan baru berdasarkan pengalamannya dalam beraktifitas secara nyata.

Berdasarkan latar belakang masalah tersebut, maka seorang guru yang inovatif dapat membangun keberhasilan bersama antara guru dan siswa. Oleh karena itu peneliti ingin mengkaji lebih jauh keefektipan model pembelajaran proyek (Project Based Learning) berbantuan clay untuk meningkatkan hasil belajar biologi pada siswa kelas XI MIPA 5 SMA Negeri 1 Semarapura semester ganjil tahun pelajaran 2015/2016.

Berdasarkan pada pemaparan di atas perlu dibuat model pembelajaran yang dapat merangkum semua teori yang telah disampaikan. Maka disini digunakanlah model pembelajaran proyek (Project Based Learning) bernamtuan Clay untuk mengatasi permasalahan rendahnya hasil belajar. Fokus permasalahan yang dicari jawabannya melalui penelitian ini dapat dirumuskan sebagai berikut: Apakah penerapan model pembelajaran proyek (project based learning) berbantuan clay dapat meningkatkan hasil belajar biologi pada siswa kelas XI IPA 5 SMA Negeri 1 Semarapura semester ganjil tahun pelajaran 2015/2016?.

\section{METODE PENELITIAN}

Penelitian ini merupakan penelitian tindakan kelas yang dilaksanakan pada semester ke-1 tahun pelajaran 2015/2016 di SMA Negeri 1 Semarapura. Lokasi sekolah sangat setrategis karena dekat dengan jalan raya yaitu beralamat di Jalan Plamboyan No 63 Semarapura sangat kondusif untuk belajar. Subjek penelitian adalah siswa kelas XI MIPA 6 yang berjumlah 38 orang dengan rincian 16 orang siswa perempuan dan 22 orang siswa laki-laki, sedangkan objek penelitian adalah hasil belajar biologi.

Penelitian ini dilaksanakan dalam dua siklus pembelajaran yang tiap 
siklusnya terdiri dari empat tahapan yaitu: 1) perencanaan tindakan, 2) pelaksanaan tindakan, 3) observasi dan evaluasi, dan 4) refleksi. Tahap perencanaan diisi dengan menyiapkan semua perangkat pembelajaran yang diperlukan diantaranya: 1) menyusun RPP, 2) menyusun LKS, 3) menyusun instrument penelitian, dan 4) menyusun rubrik/pedoman penilaian. Tahapan pelaksanaan tindakan dilakukan sesuai dengan sintak PjBL yaitu 1) Menentukan pertanyaan mendasar (Start With the Essential Question), 2) Menyusun perencanaan proyek (Design a Plan for the Project) dengan bantuan clay , 3) Menyusun jadwal (Create a Schedule), 4) Memantau peserta didik dan kemajuan proyek (Monitor the Students and the Progress of the Project), 5) Menguji hasil proyek (Assess the Outcome), dan 6) Mengevaluasi pengalaman (Evaluate the Experience), Selama melaksanakan tindakan dilakukan observasi terhadap pelaksanaan pembelajaran. Observasi dilakukan sehingga setiap tindakan dalam pelaksanaan pembelajaran dapat terobservasi. Dari semua hasil observasi dilakukan evaluasi secara kontinyu untuk mengetahui ketepatan pelaksanaan tindakan dan kebermaknaan tindakan. Pada akhir siklus dilakukan tes guna memperoleh gambaran mengenai pemahaman konseptual siswa. Untuk menilai pemahaman siswa dilaksanakan tes untuk mengukur hasil belajar. Hasil tes dianalisis secara deskriptif, yaitu dengan menentukan skor rata-rata hasil tes kemudian dibandingkan dengan kriteria yang ada (konversi nilai). Refleksi dilakukan pada akhir siklus berdasarkan hasil dari analisis tes pada akhir siklus. hasil refleksi ini digunakan sebagai dasar penyempurnaan tindakan pada siklus selanjutnya sehingga kelemahankelemahan bisa diminimalisasi.

\section{HASIL DAN PEMBAHASAN Hasil Penelitian}

Berdasarkan tujuan penelitian yang telah ditetapkan yaitu untuk meningkatkan hasil belajar biologi pada siswa kelas XI MIPA 5 SMA Negeri 1 Semarapura semester genap tahun pelajaran 2015/2016 melalui penerapan model pembelajaran proyek (proyek based learning) berbantuan clay, didapatkan data sebagai berikut: Untuk hasil belajar biologi pada siklus I diperoleh skor untuk nilai terendah dan tertinggi berdasarkan hasil tes berturut-turut adalah 40 dan 90 dengan nilai rata-rata siswa sebesar 70,53 dengan kategori kurang, jumlah siswa yang mencapai nilai $<75$ sebanyak 17 orang $(44,74 \%)$, sedangkan siswa yang mencapai nilai $\geq 75$ sebanyak 21 orang $(55,26 \%)$ dengan ketuntasan klasikal 55,26\%. Hasil belajar biologi berkaitan dengan materi yang dikaji berkategori kurang. Hasil ini menunjukkan bahwa ketuntasan secara klasikal belum tercapai, yaitu minimal sebesar $85 \%$.

Berdasarkan refleksi siklus I diketahui bahwa penerapan $\mathrm{PjBL}$ pada mata pelajaran biologi untuk bahan kajian tentang Sel, belum berlangsung dengan baik yang mengakibatkan ketuntasan klasikal belum dapat tercapai, hal ini disebabkan oleh 3 (tiga) hal: (1) Keterlambatan penyiapan sarana perasarana penunjang seperti LCD, leptop, bahan proyek (masih ada kelompok yang tidak lengkap membawa bahan yang di gunakan untuk membuat proyek, (2) Banyak di kalangan siswa yang terkejut dan masih bingung apa yang harus dilakukan dengan tugas proyek yang 
diberikan (pembuatan clay) dan (3) Pengorganisasian diskusi yang belum maksimal sehingga proses diskusi kurang baik.

Untuk memperbaiki hasil belajar pada siklus I yang belum mencapai ketuntasan klasikal, maka dilakukan penyempurnaan pada perencanaan dan pelaksanaan tindakan pada silklus II berdasarkan refleksi siklus I seperti: (1) Sebelum pengerjaan proyek dilakukan maka diadakan pengecekan terlebih dahulu terhadap bahan yang di bawa masing-masing kelompok, dengan lengkapnya semua bahan yang diperlukan tidak akan menghambat proses pengerjaan clay sistem rangka di masing-masing kelompok, dan (2) Memanfaatkan sumber belajar yang lebih variatif, seperti media cetak ataupun elektronik, perpustakaan atau bertanya kepada guru.

Berdasarkan hasil tes diakhir siklus II didapatkan data hasil belajar biologi untuk nilai terendah dan tertinggi berturutturut adalah 70 dan 100 dengan nilai ratarata siswa sebesar 85,26 dengan kategori tinggi, jumlah siswa yang mencapai nilai $<75$ sebanyak 2 orang $(5,26 \%)$, sedangkan siswa yang mencapai nilai $\geq 75$ sebanyak 36 orang $(94,74 \%)$ dengan ketuntasan klasikal 94,74\%. Itu berarti ketuntasan klasikal yang dituntut yaitu $85 \%$ terlampaui.

Gambaran mengenai deskripsi ratarata pencapaian siklus I dan siklus II hasil belajar biologi dengan $\mathrm{PjBL}$ dapat dilihat pada Gambar 4.1.

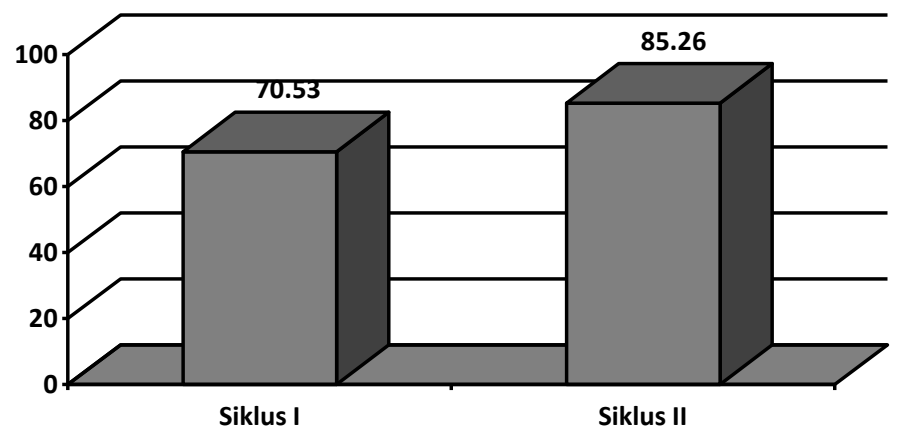

Gambar 1. Histogram Perbandingan Rata-rata Hasil Belajar Biologi Antara Siklus I dan Siklus II.

\section{PEMBAHASAN}

Berdasarkan hasil penelitian maka dapat diketahui bahwa penelitian ini konsisten dengan penelitian yang dilakukan Hutasuhut (2012) dimana hasil penelitiannya menunjukkan bahwa penerapan Project Based Learning (PjBL) dapat meningkatkan motivasi dan hasil belajar mata kuliah Pengantar Ekonomi Pembangunan pada mahasiswa jurusan Manajemen FE Unimed, didukung juga oleh hasil penelitian Prabowo (2012) yang menyatakan bahwa pembelajaran berbasis proyek mampu meningkatkan pemahaman mahasiswa atas permasalahan statistika pada perkuliahan studi kasus dan seminar. Dalam penelitian ini terlihat perbedaan yang nyata pada hasil belajar biologi antara siklus I dan siklus II, disebabkan karena PjBL adalah model pembelajaran yang memberdayakan siswa untuk memperoleh pengetahuan dan pemahaman baru berdasar pengalamannya. Dengan menerapkan model pembelajaran proyek 
dapat menyebabkan: meningkatnya motivasi siswa untuk belajar, meningkatkan kemampuan pemecahan masalah, membuat siswa menjadi lebih aktif, berhasil memecahkan problemproblem yang kompleks, menjadikan mereka lebih disiplin dan lebih menghargai waktu karena dalam pembelajaran proyek siswa dituntut mampu mengorganisasi proyek serta membuat alokasi waktu dan sumbersumber lain seperti perlengkapan untuk menyelesaikan tugas, dengan memberikan tugas proyek membuat siswa lebih terdorong untuk mengembangkan dan mempraktikkan keterampilan berkomunikasi, meningkatkan keterampilan siswa dalam mengelola sumber.

Menurut Aisah (2014) menyatakan bahwa model pembelajaran proyek membantu siswa untuk meningkatkan keterampilan sosial mereka, sering menyebabkan absensi berkurang dan lebih sedikit masalah disiplin di kelas. Siswa juga menjadi lebih percaya diri berbicara dengan kelompok orang, termasuk orang dewasa. Model pelajaran proyek juga meningkatkan antusiasme untuk belajar. Ketika anak-anak bersemangat dan antusias tentang apa yang mereka pelajari, mereka sering mendapatkan lebih banyak terlibat dalam subjek dan kemudian memperluas minat mereka untuk mata pelajaran lainnya. Antusias siswa cenderung untuk mempertahankan apa yang mereka pelajari, bukan melupakannya secepat mereka telah lulus tes. Apapun model pembelajaran yang diterapkan yang terpenting adalah bagaimana cara membuat suasana belajar menjadi menyenangkan, sehingga siswa maupun menikmati proses pembelajaran, hal ini dapat dicapai oleh PjBL karena dapat membuat suasana belajar menjadi mengasikkan dan menyenangkan sehingga siswa dapat menemukan dan merangkai ilmunya sendiri. Apalagi penerapan model pembelajaran $\mathrm{PjBL}$ dengan menggunakan media clay sebagai media pembantu untuk mempercepat penerimaan materi oleh siswa. Karena sebuah pengetahuan yang didapat sendiri misalnya dengan penemuan akan melekat lebih alam daripada pengetahuan yang di dapat dengan membaca. Menurut DePoter \& Henarki (2013) belajar menyenangkan akan memudahkan timbulnya hubungan yang dinamis dalam lingkungan kelas, interaksi yang timbul pada siswa merupakan kerangka untuk belajar.

Menurut Nggermanto (2003) ada tiga tipe modalitas belajar manusia yaitu tipe visual (belajar dengan cara melihat), auditorial (belajar dengan cara mendengar), dan kinestesial (belajar dengan cara bergerak, bekerja dan menyentuh). Apabila seseorang mampu mengenali tipe belajar dan melakukan pembelajaran yang sesuai maka belajar akan terasa sangat menyenangkan dan memberikan hasil yang optimal. Pembelajaran dapat dilakukan di berbagai tempat dan tidak mengambil bentuk kelas sekolah. Tapi pada kenyataannya kebanyakan orang akan cenderung menggunakan salah satu dari ketiga modal tersebut. Setiap orang mempunyai gaya yang berbeda-beda dan selalu mempunyai kecenderungan sesuai dengan hobi dan kebiasaan mereka. Seorang guru juga akan kesulitan untuk menentukan model pembelajaran yang dapat merangkum kebiasaan siswa belajar dengan modalitas belajar yang berbeda-beda. Terkadang guru hanya menekankan modalitas visual saja, auditorial atau kinestika saja. Itu akan 
membuat hasil belajar tidak akan maksimal dicapai oleh semua anggota kelas yang beragam. Tetapi dengan menggunakan $\mathrm{PjBL}$ yang hasilnya disajikan melalui media audiovisual dapat mengakumulasi semua tipe modalitas belajar manusia, baik tipe visual, auditorial, dan kinestesial.

Semua model pembelajaran yang diterapkan oleh seorang guru keberhasilannya akan diukur, salah satu alat ukurnya yaitu peningkatan hasil belajar siswa. Hasil belajar adalah pencapaian bentuk perubahan perilaku yang cenderung menetap dari ranah kognitif, afektif, dan psikomotoris dari proses belajar yang dilakukan dalam waktu tertentu. Berdasarkan hasil penelitian tindakan kelas yang dilakukan dengan hasil yang sudah ditunjukan maka PjBL berbantuan clay sudah terbukti dapat meningkatkan hasil belajar siswa kelas XI MIPA 5 di SMA Negeri 1 Semarapura.

\section{PENUTUP}

Berdasarkan hasil analisis data dan pembahasan yang telah diuraikan dapat dirumuskan simpulan: PjBL berbantuan Clay dapat meningkatkan hasil belajar biologi pada siswa kelas XI MIPA 5 SMA Negeri 1 Semarapura semester ganjil tahun pelajaran 2015/2016.

Berdasarkan temuan-temuan dan simpulan pada penelitian ini, maka sebagai tindak lanjut dari penelitian ini dikemukakan beberapa saran yang dapat direkomendasikan adalah sebagai berikut: 1) untuk guru, dalam usaha memperoleh hasil belajar biologi yang optimal, guru sebaiknya menyiapkan perangkat pembelajaran lebih awal, melaksanakan pembelajaran dengan menyenangkan dengan memberikan waktu pada siswa lebih banyak untuk berdiskusi dan menggali ilmunya sendiri dengan panduan LKS yang sudah diberikan lebih awal, memperhatikan kreativitas siswa, lebih sabar menghadapi berbagai persoalan yang ditanyakan oleh siswa, karena dalam PjBL lebih menekankan pada kreatifitas siswa sedangkan guru hanya berfungsi sebagi pasilitator dalam proses pembelajaran, membiasakan memberikan penghargaan atau pujian kepada siswa yang berhasil akan mampu meningkatkan semangat belajar siswa, 2) untuk siswa, dalam menyongsong era globalisasi dimana dunia seolah-olah tanpa batas lagi, maka sumber daya manusia menjadi satu-satunya pilihan untuk dapat tetap bertahan dan eksis di negeri sendiri. Karena pada era global tenaga asing sudah masuk ke negeri kita untuk sama-sama bersaing berebut lapangan kerja, maka disini dituntut keahlian khusus dan kreatifitas tinggi untuk dapat berkompetisi. Oleh karena itu tidak ada pilihan lain bagi para siswa selain belajar untuk meningkatkan kualitas intelektual dan kreativitas. Belajar haruslah benar-benar menjadi suatu kebutuhan hidup, bukan hanya sekedar ikut-ikutan, belajar secara kontektual dan memupuk kemampuan berpikir kreatif sangat penting bagi siswa karena di luar bangku sekolah yang akan dihadapi adalah masalah-masalah nyata yang memerlukan pemecahan untuk mendapat solusi yang tepat terhadap berbagai persoalan yang dihadapi baik didunia kerja nantinya maupun di masyarakat, 3) Untuk lembaga sekolah dan pengelola, sudah saatnya bagi pengelola sekolah untuk merubah paradigma bahwa sekolah yang baik adalah sekolah yang memiliki gedung yang megah, pengelola sekolah seharusnya memiliki paradigma baru yaitu sekolah 
yang baik adalah sekolah yang memiliki sarana-perasarana belajar memadai baik kuantitas maupun kualitasnya dan memiliki guru-guru yang profesional. Oleh karena itu pengelola sekolah terutama kepala sekolah dan komite supaya menyiapkan anggaran yang cukup guna terus-menerus meningkatkan saranaperasarana sekolah dan meningkatkan kualifikasi guru-gurunya. Dengan saranaperasarana yang memadai dan guru-guru yang profesional, maka hasil belajar siswa akan dapat tercapai secara optimal.

\section{DAFTAR RUJUKAN}

Anon. (2015, 26 Maret). Mendikbud: Kemampuan Matematika dan Membaca Anak Lemah. Bali Post.

DePorter, B \& Hernacki, M. (2013). Quantum Learning: Membiasakan Belajar Nyaman dan Menyenangkan. Penerjemah: Alwiyah Abdurrahman. Edisi I. Bandung: Kaifa

Kemendikbud. (2014). Materi Pelatihan Guru Implementasi Kurikulum 2013 Tahun Ajaran 2014/2015: Mata Pelajaran Biologi SMA/SMK. Jakarta. Badan Pengembangan Sumber Daya Manusia Pendidikan dan Kebudayaan dan Penjaminan Mutu Pendidikan Kementerian Pendidikan dan Kebudayaan.

Nggermanto, A. (2003). Quantum Quotient (Kecerdasan Quantum). Cetakan ke-5. Bandung: Nuansa Cendekia.

Prabowo, A. (2012). Pembelajaran Berbasis Proyek Untuk Meningkatkan Pemahaman Mahasiswa atas Permasalahan Statistika pada Perkuliahan Studi Kasus dan Seminar. Journal:vol 3 No 2. Tersedia pada: journal.unnes.ac.id. dunduh: 24 desember 2015.
Solihah, D. (2013). Pengaruh metode pembelajara PQ4R terhadap penguasaan konsep dan kemampuan bertanya pada siswa SMA. Universitas pendidikan Indonesia.

Utasuhut, S (2012). Implementasi Pembelajaran Berbasis Proyek (Project-Based Learning) Untuk Meningkatkan Motivasi Dan Hasil Belajar Mata Kuliah Pengantar Ekonomi Pembangunan Pada Jurusan Manajemen Fe Unimed. Journal. Tersedia pada: Ejournal.unri.ac.id. diunduh: 12 Agustus 2015. 